\title{
APLIKASI PENGELOLAHAN DATA TRI DHARMA PERGURUAN TINGGI PADA UNIVERSITAS BINA INSAN LUBUKLINGGAU BERBASIS WEB
}

\author{
Asep Toyib Hidayat ${ }^{1 *}$, Ahmad Sobri ${ }^{2}$ \\ Program Studi Sistem Informasi, Universitas Bina Insan, Lubuklinggau ${ }^{1}$ \\ Program Studi Informatika, Universitas Bina Insan, Lubuklinggau ${ }^{2}$ \\ Email : asep_toyib_hidayat@ univbinainsan.ac.id ${ }^{1}$,ahmad_sobri@ univbinainsan.ac.id ${ }^{2}$
}

\begin{abstract}
Abstrak
Tri dharma perguruan tinggi merupakan tugas pokok dan kewajiban dosen yang harus dilaksanakan, tri dharma perguruan tinggi terdiri dari tiga poin yaitu pendidikan, penelitian, dan pengabdian kepada masyarakat, namun saat ini Universitas Bina Insan Lubuklinggau belum memiliki sebuah aplikasi yang dapat membantu pihak Universitas Bina Insan Lubuklinggau serta dosen dalam melakukan pengolahan data tri dharma perguruan tinggi yang mengakibatkan data tri darma perguruan tinggi dari masing masing dosen tidak dapat tertata dan tersimpan dengan baik, maka dari itu diperlukan sebuah aplikasi yang dapat membantu pihak Universitas Bina Insan Lubuklinggau dan dosen dalam melalukan pengolahan data tri darma tersebut. Metode pengembangan sistem yang digunakan dalam penelitian ini yakni metode waterfall, metode waterfall mempunyai langkah -langkah meliputi: analisa kebutuhan, desain sistem, penulisan kode program, pengujian program, dan penerapan (implementasi). Hasil dari penelitian ini dapat disimpulkan bahwa dengan adanya aplikasi ini dapat mempermudah pengelolahan data maupun membuat laporan pada tri dharma pergruan tinggi pada universitas bina insan lubuklinggau sehingga data yang dihasilkan dapat tertata dan tersimpan lebih baik.
\end{abstract}

Kata Kunci : Aplikasi; Tri Dharma; Web; Waterfall

\begin{abstract}
The Tri Dharma of Higher Education is the main task and obligation of lecturers that must be carried out, tri Dharma of Higher Education consists of three points, namely education, research, and community service, but currently the Bina Insan Lubuklinggau University does not yet have an application that can help the Bina Insan Lubuklinggau University as well as lecturers in processing the tri dharma higher education data which results in the tri dharma higher education data from each lecturer not being organized and stored properly, therefore an application is needed that can assist the Bina Insan Lubuklinggau University and lecturers in processing the tri dharma data. The system development method used in this research is the waterfall method, the waterfall method includes the following steps: needs analysis, system design, writing program code, testing programs, and implementing (implementation). The results of this study can be concluded that this application can facilitate data management and make reports on the Tri Dharma of Higher Education at Bina Insan Lubuklinggau University so that the resulting data can be organized and stored better.
\end{abstract}

Keywords: Application; Tri Dharma, Web; Waterfall 


\section{PENDAHULUAN}

Tri dharma perguruan tinggi merupakan tugas pokok dan kewajiban dosen yang harus dilaksanakan, tri dharma perguruan tinggi terdiri dari tiga poin yaitu pendidikan, penelitian, dan pengabdian kepada masyarakat. Ketiga dharma saling berkaitan antara lain dharma pertama (pendidikan: teoretik) dan kedua (penelitian: inovasi) harus secara konkrit mendukung dharma ketiga (pengabdian: transformasi). Dalam pelaksanaan penelitian terkandung misi penting yaitu demi kemaslahatan masyarakat. Artinya, masyarakat tetap menjadi fokus, terutama dalam penelitian social. Maka, hasil dan temuan penelitian harus ada feedback nya ke masyarakat. Penelitian tersebut harus ditindaklanjuti dengan pengabdian kepada masyarakat yang sesuai demi kepentingan masyarakat. Penelitian harus mempunyai dampak positif bagi masyarakat [1].

Hasil dari studi lapangan yang telah dilakukan didapatkan bahwa saat ini Universitas Bina Insan belum memiliki aplikasi yang dapat membantu pihak universitas dalam melakukan pengeolahan data tri dharma peruguruan tinggi yang telah dilakukan oleh dosen, sehingga data-data mengenai tri dharma perguruan tinggi yang telah dilakukan tidak tersusun dan tersimpan secara baik.

Sejalan dengan hasil dari studi lapangan yang telah dilakukan makan penulis selanjutnya melakukan literature review terhadap hasil penelitian yang telah dilakukan sebelumnya, penelitian-penelitian yang membahas mengenai pengolahan data tri dharma perguruan tinggi antara lain, penelitian yang dilakukan telah dilakukan, dalam penelitian ini membahas pengolahan data penelitian dan pengabdian kepada masyarakat, dengan penelitian ini dapat mempermudah dan mempercepat pihak LPPM dalam mendata dan mengevaluasi penelitian dan pengabdian masyarakat yang telah dilakukan oleh dosen maupun mahasiswa serta dengan aplikasi ini dapat digunakan sebagai bahan evaluasi pimpinan dalam mengukur kinerja penelitan dan pengabdian masyarakat yang telah dilakukan oleh dosen maupun mahasiswa dan dapat mempercepat pembuatan laporan kinerja penelitian dan pengabdian masyarakat dalam bentuk grafik [2], dalam penelitian ini hanya membahasa penelitian dan pengabdian masyarakat tidak untuk pendidikan.

Penelitian lainnya dengan tujuan penerapan Trello dalam membantu program studi untuk memantau kegiatan Tri Dharma Perguruan Tinggi dosen pada masa pandemi covid-19. Trello merupakan suatu aplikasi visual dengan gaya kanban (kartu catatan atau note) yang digunakan untuk mengorganisai pekerjaan. Penerapan Trello sebagai tools dalam melakukan emonitoring tridharma Perguruan Tinggi dosen program studi sangat bermanfaat. Melalui trello, Kaprodi dapat mengetahui sejauh mana progress yang dilakukan dosen pada kegiatan Tri Dharma Perguruan Tinggi [3], penelitian ini tidak melibatkan pihak LPPM atau sejenis nya dalam penggunaan aplikasi tersebut.

Berdasarkan hasil literature review dan studi lapangan yang telah dilakukan maka tujuan dari penelitian ini adalah untuk membangun sebuah aplikasi berbasis website dimana aplikasi ini akan dibangun menggunakan framework Codeigniter yang dapat mempermudah pihak Universitas Bina Insan dalam melakukan pendataan dan pengelolaan data tri dharma perguruan tinggi sehingga data yang dihasilkan dapat tersusun dengan rapi dan baik. 


\section{TINJAUAN PUSTAKA}

\subsection{Pendidikan}

Tujuan pendidikan nasional ialah untuk meningkatkan kualitas manusia, yaitu manusia yang beriman, dan bertakwa terhadap Tuhan Yang Maha Esa, berbudi pekerti luhur, berkepribadian, mandiri, terampil, berdisiplin, beretos, kerja, professional, bertanggungjawab, dan produktif serta sehat jasmani, dan rohani, serta mempunyai rasa tanggungjawab kemasyarakatan dan kebangsaan, pendidikan merupakan salah satu investasi yang sangat penting untuk menyiapkan sumber daya manusia (SDM) khususnya dalam pesaingan di era global saat ini. Melalui pendidikan, bangsa Indonesia akan mampu merencanakan dan menyiapkan tenaga terdidik yang mempunyai kemampuan bersaing dengan negara lain [1].

\subsection{Penelitian}

Karya Ilmiah merupakan suatu bentuk hasil kegiatan ilmiah yang dilakukan oleh dosen yang berkaitan dengan proses-proses ilmiah. Karya Ilmiah adalah hasil penelitian atau pemikiran yang dipublikasikan dan ditulis memenuhi Kaidah Ilmiah dan Etika Keilmuan. Dari definisi ini tampak bahwa Karya Ilmiah tidak hanya mencakup suatu hasil penelitian [4].

\subsection{Pengabdian Kepada Masyarakat}

Pengabdian adalah pegamalan hasil penelitian yang berupa IPTEKS (Ilmu pengetahuan, teknologi dan seni) yang dilakukan oleh perguruan tinggi secara melembaga melalui metode ilmih langsung kepada masyarakat (diluar kampus yang tidak terjangkau oleh program pendidikan formal) yang membutuhkannya, dalam upaya mensukseskan pembangunan dan mengembangkan SDM yang berkualitas [5].

\subsection{UML}

Unified Modeling Language (UML) adalah salah satu standar bahasa yang banyak digunakan di dunia industri untuk mendefinisikan requirment, membuat analisis \& desain, serta menggambarkan arsitektur dalam pemrograman berorienasi objek [6].

Alat bantu yang digunakan dalam perancangan berorientasi objek berbasiskan UML adalah sebagai berikut :

a. Use Case Diagram, Use case diagram merupakan pemodelan untuk kelakuakn (behavior) sistem informasi yang akan dibuat. Use case digunakan untuk mengetahui fungsi apa saja yang ada di dalam sistem informasi dan siapa saja yang berhak menggunakan fungsifungsi tersebut.

b. Diagram Aktivitas (Activity Diagram) Activity Diagram menggambarkan workflow (aliran kerja) atau aktivitas dari sebuah sistem atau proses bisnis

c. Diagram Kelas (Class Diagram) Merupakan hubungan antar kelas dan penjelasan detail tiap-tiap kelas di dalam model desain dari suatu sistem, juga memperlihatkan aturan-aturan dan tanggung jawab entitas yang menentukan perilaku sistem. Class Diagram juga menunjukkan atributatribut dan operasi

\subsection{Web}

Website adalah kumpulan halamanhalaman web yang terdapat dari sebuah domain yang mengandung informasi. Sebuah web dapat dibangun berdasarkan sistem informasi yang telah dirancang sebelum nya sehingga sebuah web dapat digunakan sebagai sarana untuk mengetahui dan memeberi informasi kepada masyarakat luas tentang informasi yang dibutuhkan [7]. 


\subsection{Framework Codeigniter}

Codeigniter adalah framework yang bekerja pada bahasa pemrograman PHP yang digunakan untuk mempermudah programmer dalam proses membangun sebuah aplikasi berbasis web, setelah menyelesaikan pembuatan sistem dengan framework codeigniter didapatkan kesimpulan bahwa dengan adanya sistem ini dapat mempermudah masyarakat untuk memesan dan mengetahui informasi yang cocok [8].

\section{METODOLOGI PENELITIAN}

Kerangka berpikir pada Aplikasi Pengelolahan Data Tri dharma Perguruan Tinggi Universitas Bina Insan Lubuklinggau berbasis web, dimana pada kerangka berpikir ini memiliki identifikasi masalah yang selanjutnya melakukan studi lapangan dan literature review mengenai topik penelitian yang merupakan latar belakang masalah dari penelitian, dan menetapkan judul serta menentukan metodologi penelitian yang akan digunakan, metodologi penelitian tersebut terbagi menjadi dua yakni metoode pengumpulan data dan metode pengembangan sistem. Hasil yang didapatkan dari penelitian ini kemudian diberi kesimpulan dan saran untuk penelitian selanjutnya

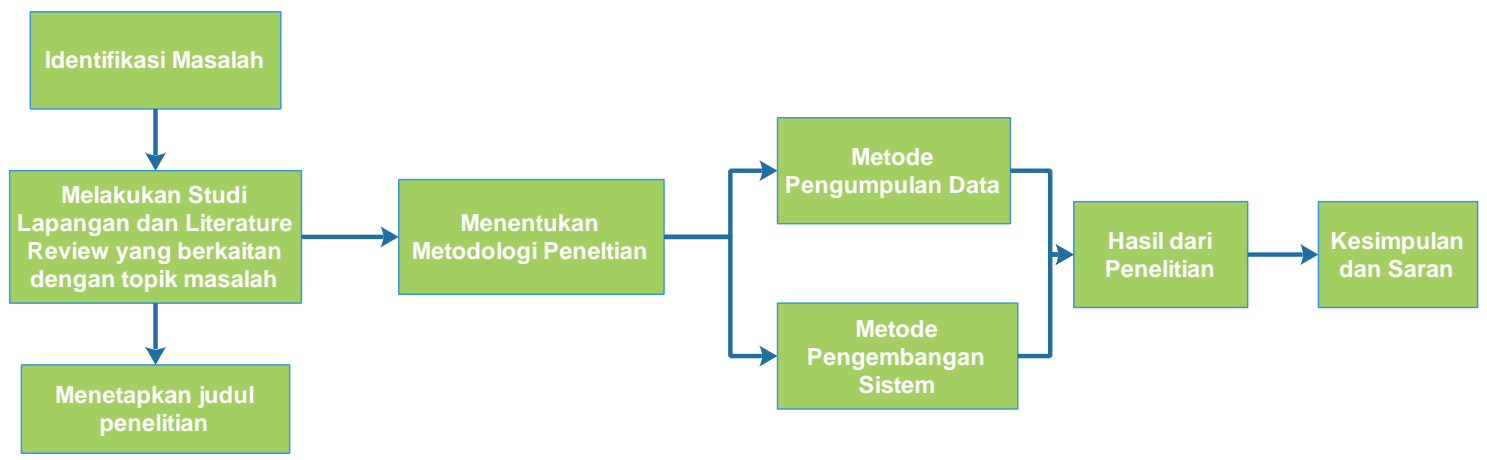

Gambar 1 Kerangka Berpikir

Sumber Data : Hasil Penelitian (2020)

\subsection{Metode Pengumpulan Data}

Proses pengumpulan data dalam penelitian ini adalah [9]:

a. Metode Observasi

Penulis melakukan pengamatan langsung di Universitas Bina Insan untuk mendapatkan data terkait tentang Tri Dharma Perguruan Tinggi.

b. Metode Wawancara

Penelitian ini dilakukan dengan mewawancarai unsur pimpinan dan pimpinan yang terkait dengan tri dharma perguruan tinggi.

c. Metode Dokumentasi

Penulis mencari dokumen-dokumen yang ada hubungannya dengan masalah-masalah serta melengkapi data-data yang diperlukan dalam penulisan penelitian ini.

d. Teknik Kepustakaan

Studi kepustakaan adalah suatu teknik atau cara pengumpulan data atau informasi yang dilakukan dengan cara membaca buku-buku ilmiah, laporan penelitian, kenangan-kenangan ilmiah, dan sebagainya yang berhubungan dengan permasalahan terkait.

\subsection{Metode Pengembangan Sistem}

Dalam menunjang pembuatan penelitian ini, maka penulis menggunakan metode pengembangan sistem waterfall untuk penyusunan penelitian ini, alasan penulis menggunakan metode 
pengembangan sistem waterfall adalah karena metode ini tahapan dan juga urutan dari metode yang dilakukan berurutan dan berkelanjutan seperti layaknya sebuah air terjun [10][11].

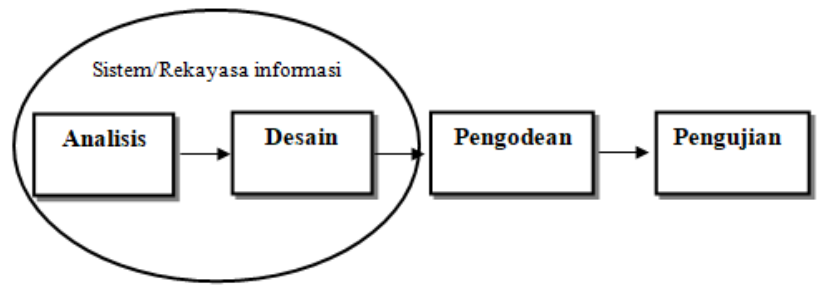

Gambar 2 Metode Pengembangan Sistem Sumber [10][11]

Tahapan - tahapan model waterfall adalah :

1. Analisis Kebutuhan Perangkat Lunak

Dalam analisa kebutuhan ini bertujuan untuk menganalisis kebutuhan yang dibutuhkan dalam perancangan baik berupa dokumen maupun sumber lain yang dapat membantu dalam menentukan solusi permasalahan yang ada baik dari sisi user maupun admin.

Berdasarkan pengamatan di lapangan, Universitas Bins Insan Lubuklinggau didapatkan bahwa belum adanya sistem pengolahan data tridarma perguruan tinggi yang dapat mendata tri dharma perugruan tinggi yang telah dilakukan oleh dosen. Maka dari itu akan dibuat aplikasi pengelolahan data tridarma perguruan tinggi Universitas Bina Insan. Sistem ini di buat sebagai alat bantu untuk menginputkan data tri dharma perguruan tinggi yang dapat digunakan untuk mengajukan kenaikan Pangkat.

\section{Desain}

Dalam Desain perangkat lunak menggunakan permodelan basis data dengan menggunakan UML (Unified Modeling Language).

\section{a. Usecase Diagram}

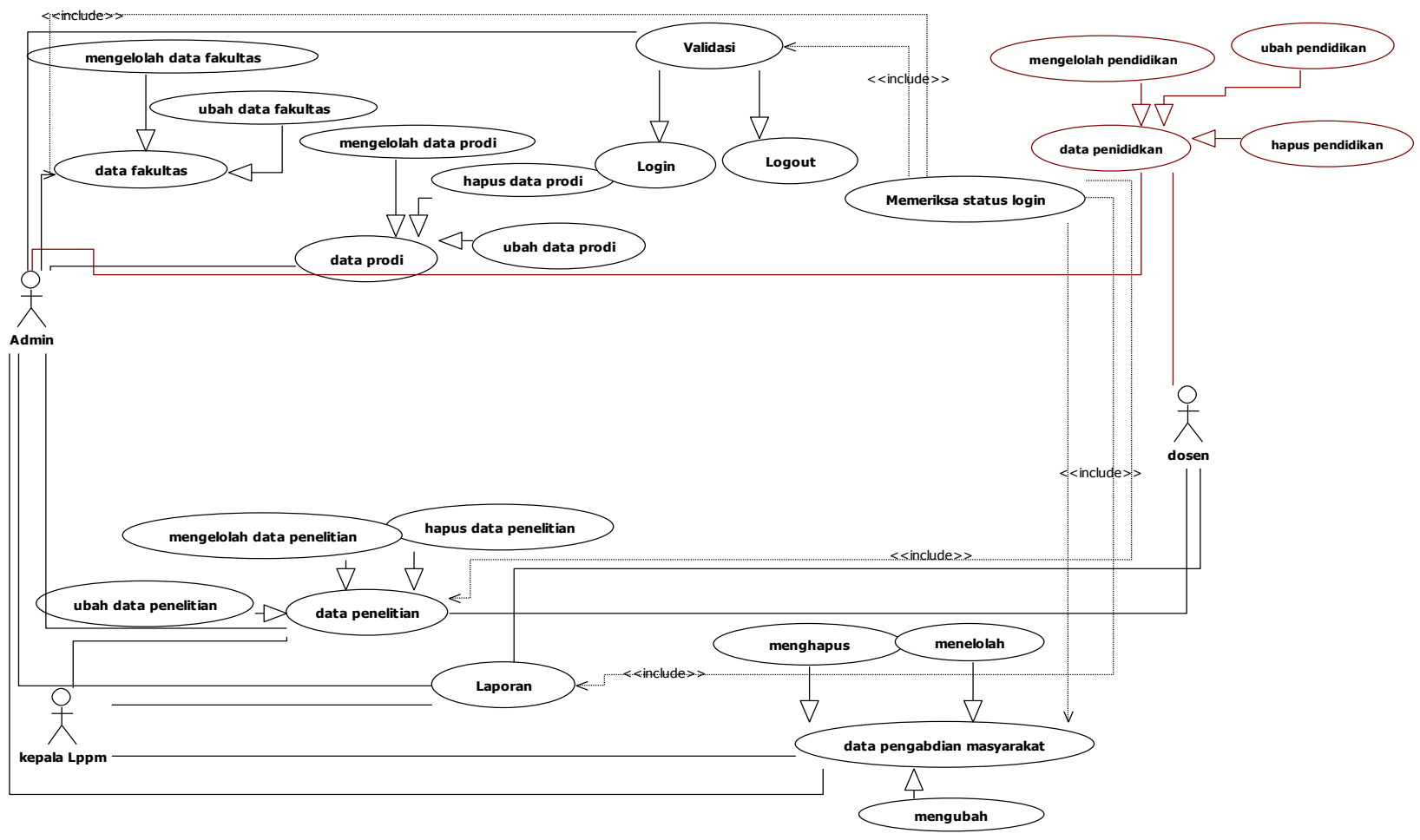

Gambar 3 Usecase Diagram

Sumber Data : Hasil Penelitian (2020) 
Dari gambar 3 ditas diketahui terdapat tiga aktor yang terlibat dalam penelitian ini yaitu admin, kepala lppm dan dosen, admin adalah orang yang bertugas dan memiliki hak akses untuk melakukan pengolahan data penelitian, luaran penelitian, data mahasiswa, data universitas, laporan data dosen, data pengabdian masyarakat dan data prodi, kepala lppm adalah orang yang bertugas dan memiliki hak untuk mengelolah data penelitian,luaran penelitian,laporan,data pengabdian masyarakat, memilikai hak akses untuk melihat laporan dan dosen adalah orang yang memiliki hak akses untu mengelolah data penelitian,luaran penelitian data mahasiswa dan laporan

\section{b. Class Diagram}

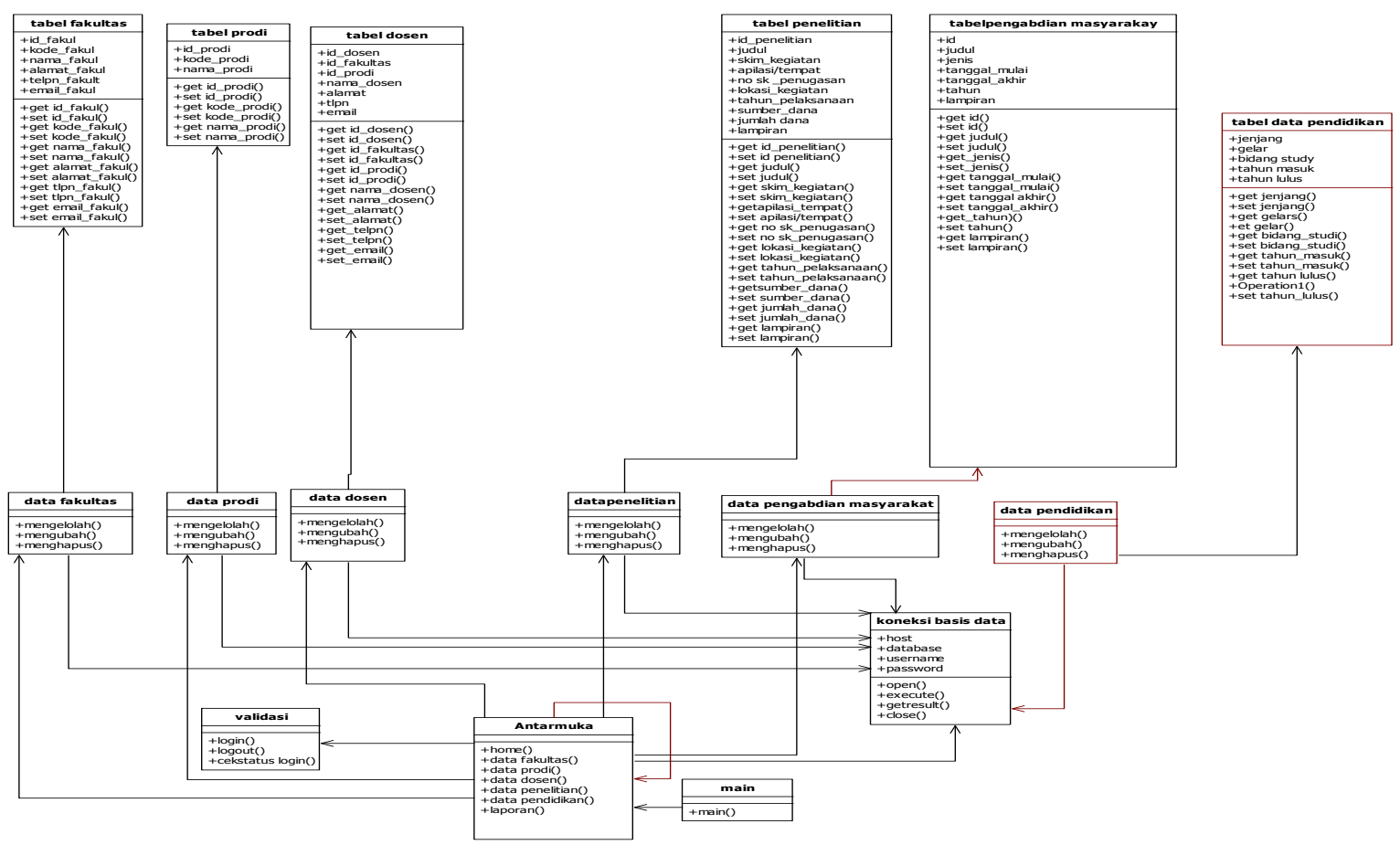

Gambar 4 Class Diagram

Sumber Data : Hasil Penelitian (2020)

Dari gambar 4 class diagram diatas diketahui bahwa terdapat beberapa tabel database dalam penelitian ini yaiut tabel fakultas, tabel prodi, tabel dosen, tabel penelitian, tabel pengabdian masyarakat dan tabel pendidikan, dimana pada setiap tabel mempunyai field-field yang saling terhubung satu sama lain dengan antar muka sistem

3. Pembuatan Kode Program

Dalam tahap ini peneliti mulai membangun aplikasi sesuai dengan analisis kebutuhan untuk membuat form input dan output dengan aplikasi berbasis web dengan bahasa pemrograman php dan mysql.

4. Pengujian

Pada tahapan ini pengujian program dilakukan dengan menggunakan BlacBox Testing dengan harapan bahwa perancangan yang sudah dibuat dapat berjalan dengan sesuai keinginan.

5. Pendukung (Support) atau Pemeliharaan Dalam proses pemeliharaan ini penulis mengupayakan pengembangan sistem yang telah di rancang terkait software dan hardware dapat dibuat maksimal agar aplikasi dapat berjalan dengan baik [10]. 


\section{HASIL DAN PEMBAHASAN}

Pada bab ini membahas mengenai hasil dari rancangan aplikasi data tri dharma perguruan tinggi berbasis web pada universitas bina insan lubuklinggau setelah dirancang dan di implementasikan.

\subsection{Tampilan Aplikasi}

1 Halaman login Admin

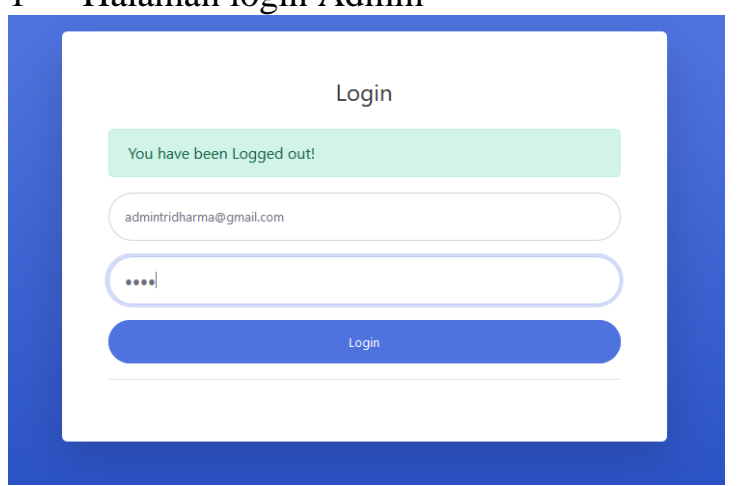

Gambar 5 Halaman login Admin

Sumber : Hasil Penelitian (2020)

Halaman login admin digunakan untuk masuk ke halaman utama aplikasi pengelolahan data tri dharma perguruan tinggi dengan cara mengimputkan username dan password sistem akan melakukan validasi password apabila salah memasukan username atau password.

2 Halaman Branda Admin

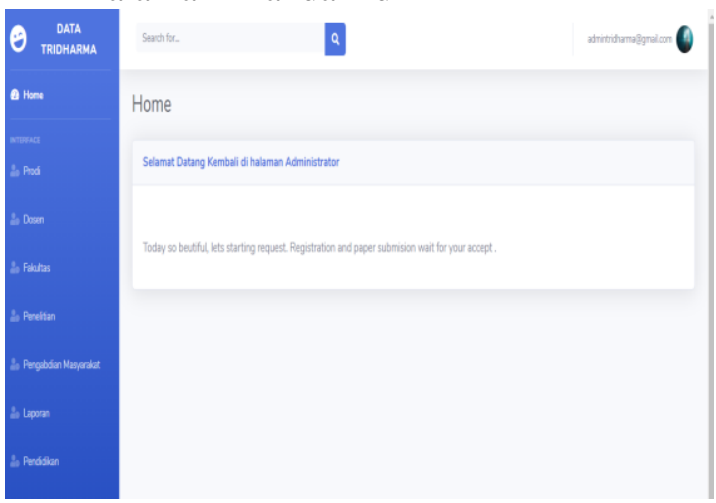

Gambar 6 Halaman Branda Admin Sumber : Hasil Penelitian (2020)

Halaman beranda digunakan untuk menampilkan data yang di input oleh admin, pada halaman ini admin memiliki hak penuh pada aplikassi pengelolahan data.
3 Halaman data prodi

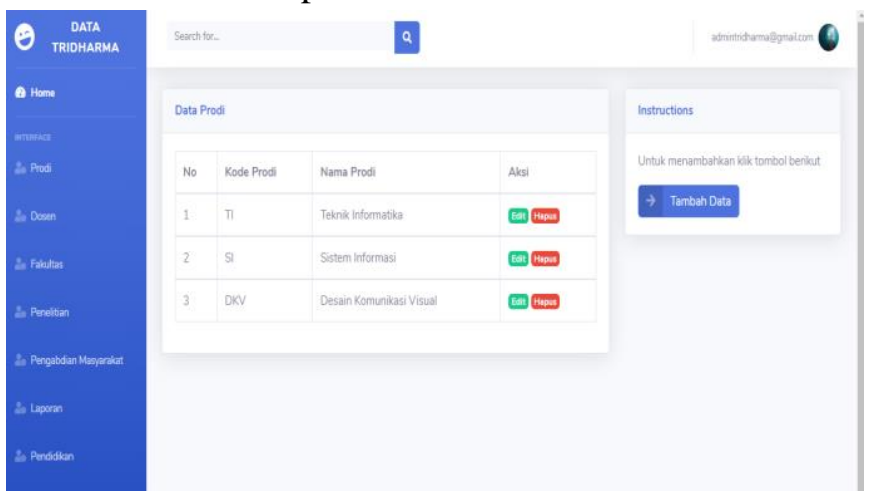

Gambar 7 Halaman data prodi

Sumber : Hasil Penelitian (2020)

4 Halaman menu Fakultas

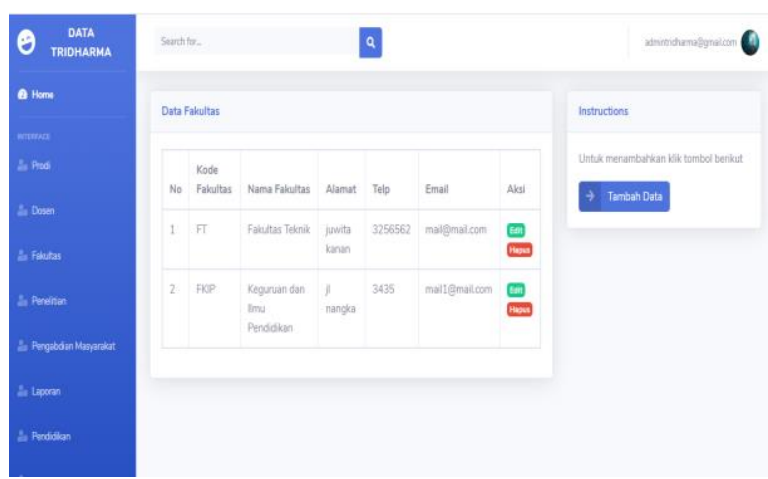

Gambar 8 Halaman menu Fakultas Sumber : Hasil Penelitian (2020)

Halaman nemu fakultas menampilkan data fakultas pada aplikasi tri dharma perguruan tinggi, user yang memiliki akses antara lain admin,dosen,dan kepala lppm untuk menginput data fakultas

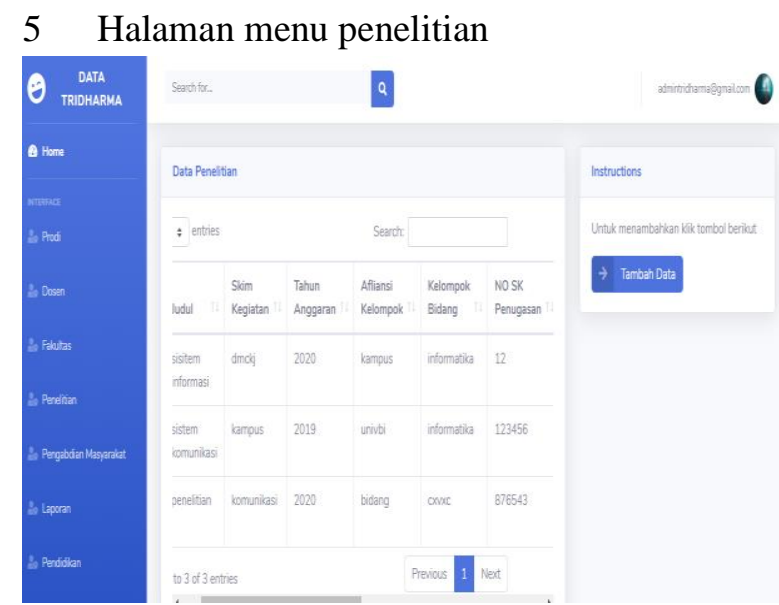

Gambar 9 Halaman menu penelitian Sumber : Hasil Penelitian (2020) 
Halaman nemu penelitian menampilkan data penelitian pada aplikasi tri dharma perguruan tinggi, user yang memiliki akses antara lain admin,dosen,dan kepala lppm memiliki akses untuk menginput data penelitian

6 Halaman menu pengabdian masyarakat
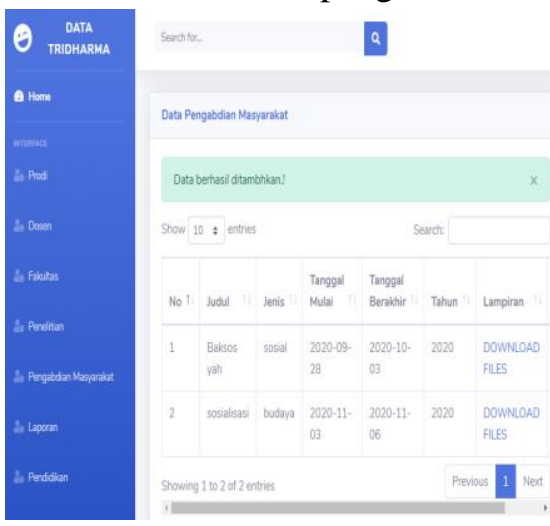

Gambar 10 Halaman menu pengabdian masyarakat

Sumber : Hasil Penelitian (2020)

Halaman nemu pengabdian masyarakat menampilkan data penelitian pada aplikasi tri dharma perguruan tinggi, user yang memiliki akses antara lain admin,dosen,dan kepala lppm memiliki akses untuk menginput data pengabdian masyarakat.
7 Halaman menu pendidikan

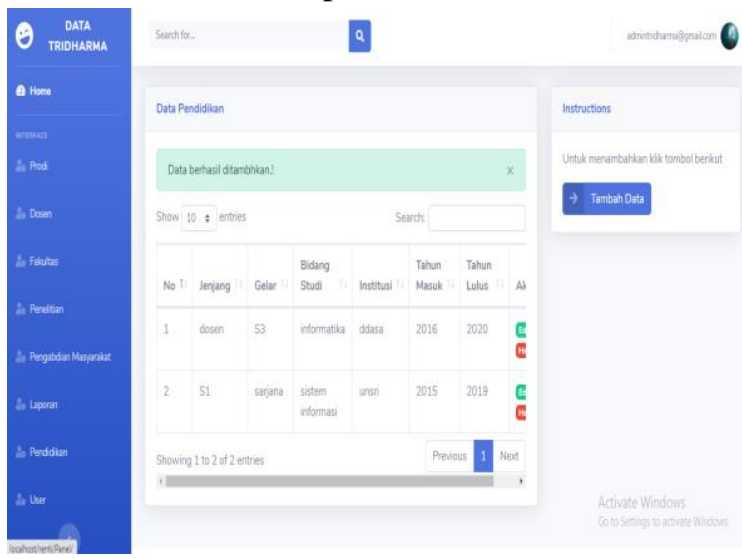

Gambar 11 Halaman menu pendidikan Sumber : Hasil Penelitian (2020)

Halaman menu pendidkan yang di kelolah oleh dosen dan admin kepala lppm memiliki akses untuk menginput data pendidikan.

8 Halaman menu laporan

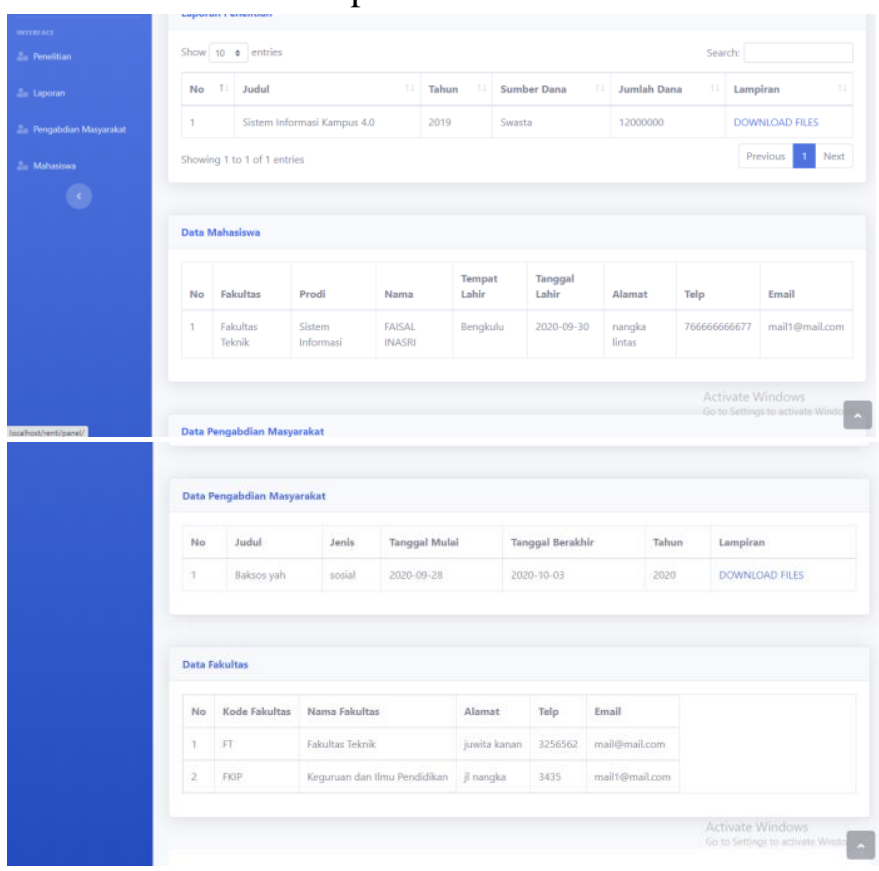

Gambar 12 Halaman menu laporan Sumber : Hasil Penelitian (2020) 


\subsection{Pengujian Sistem}

Pada pengujian sistem pengguna akan menguji semua fungsional sistem yang terkait baik dari segi input data, laporan serta validasi form-form dan lainya. Di mulai dari halaman login hingga logout dari sistem yang dibuat dengan memasukan pengujian melalui deskripsi, kemudian kesesuaian Antara hasil yang di diharapkan dengan kesuksesan, adapun table pengujan sistem dapat dilihat sebagai berikut :

\begin{tabular}{|c|c|c|c|c|}
\hline \multirow[t]{2}{*}{ No } & \multirow{2}{*}{ Pengujian } & \multirow{2}{*}{ Pembahasan } & \multicolumn{2}{|c|}{ Keterangan } \\
\hline & & & $\begin{array}{l}\text { Tidak } \\
\text { berhasil }\end{array}$ & Berhasi \\
\hline 1 & Halaman depan & $\begin{array}{l}\text { User membuka aplikasi } \\
\text { halaman depan }\end{array}$ & & $\sqrt{ }$ \\
\hline 2 & $\begin{array}{l}\text { Halaman login } \\
\text { Administrator }\end{array}$ & $\begin{array}{l}\text { User admin berhasil } \\
\text { melakukan login dan } \\
\text { menampilkan halaman } \\
\text { data admin }\end{array}$ & & $\sqrt{ }$ \\
\hline 3 & $\begin{array}{l}\text { Halaman } \\
\text { mengelolah prodi }\end{array}$ & $\begin{array}{l}\text { User admin berhasil } \\
\text { menampilkan dan } \\
\text { mengelolah data prodi }\end{array}$ & & $\sqrt{ }$ \\
\hline 4 & $\begin{array}{l}\text { Halaman } \\
\text { mengelolah data } \\
\text { mahasiswa }\end{array}$ & $\begin{array}{lr}\text { Admin melihat dan } \\
\text { mengelolag } \\
\text { mahasiswa }\end{array}$ & & $\sqrt{ }$ \\
\hline 5 & $\begin{array}{l}\text { Halaman } \\
\text { mengelolah data } \\
\text { dosen }\end{array}$ & $\begin{array}{l}\text { Admin berhasil melihat } \\
\text { dan mengelola data } \\
\text { dosen }\end{array}$ & & $\sqrt{ }$ \\
\hline 6 & $\begin{array}{l}\text { Halaman } \\
\text { mengelolah data } \\
\text { fakultas }\end{array}$ & $\begin{array}{l}\text { Admin mengelolah dan } \\
\text { melihat data fakultas }\end{array}$ & & $\checkmark$ \\
\hline 7. & $\begin{array}{l}\text { Halaman } \\
\text { mengelolah data } \\
\text { penelitian }\end{array}$ & $\begin{array}{lr}\text { Admin } & \text { berhasil } \\
\text { mengelolah data } \\
\text { penelitian dan membuat } \\
\text { laporan }\end{array}$ & & $\sqrt{ }$ \\
\hline 8 & $\begin{array}{l}\text { Halaman } \\
\text { mengelolah data } \\
\text { pengebdian } \\
\text { masyarakat } \\
\end{array}$ & $\begin{array}{lr}\text { Admin } & \text { berhasil } \\
\text { mengelolah data } & \text { pengabdian masyarakat }\end{array}$ & & $\sqrt{ }$ \\
\hline 9 & $\begin{array}{l}\text { Halaman melihat } \\
\text { laporan dosen }\end{array}$ & $\begin{array}{l}\text { Admin berhasil melihat } \\
\text { data laporan dari dosen }\end{array}$ & & $\sqrt{ }$ \\
\hline 10 & $\begin{array}{l}\text { halaman menu } \\
\text { logout }\end{array}$ & $\begin{array}{l}\text { Admin berhasil } \\
\text { melakukan logout }\end{array}$ & & $\sqrt{ }$ \\
\hline 11 & $\begin{array}{l}\text { Halaman menu } \\
\text { login dosen }\end{array}$ & $\begin{array}{l}\text { User dosen berhasil } \\
\text { melakukan login }\end{array}$ & & $\sqrt{ }$ \\
\hline 12 & $\begin{array}{l}\text { Halaman utama } \\
\text { data dosen }\end{array}$ & $\begin{array}{l}\text { User dosen berhasil } \\
\text { masuk kemenu utama } \\
\text { tampilan data dosen }\end{array}$ & & $\sqrt{ }$ \\
\hline
\end{tabular}




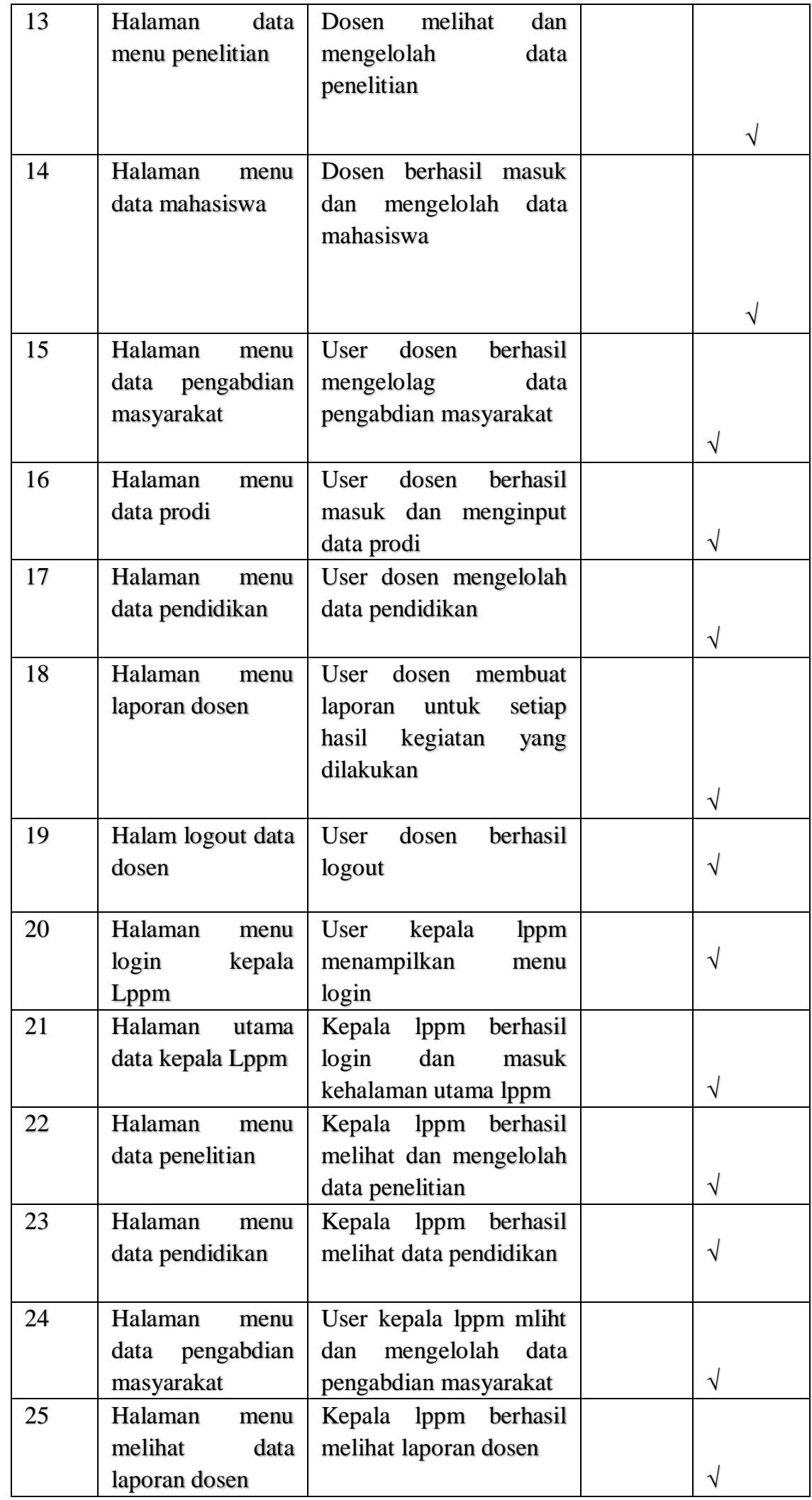

Sumber : Hasil Penelitian (2020) 
V. KESIMPULAN

Berdasarkan hasil penelitian dan pembahasan penulis membuat suatu kesimpulan sebagai berikut :

1 Dengan adanya aplikasi tri dharma perguruan tinggi dapat mempermudah pengelolahan data maupun membuat laporan pada tri dharma perguruan tinggi universitas bina insan lubuklinggau

2 Mempermudah bagi kepala lppm untuk melihat laporan atau data yg berkaitan dengan penelitian dan pengabdian masyarakat

3 Meningkatkan kinerja dan mempercepat proses pengimputan data dengan mengunakan aplikasi pengelolahan data tri dharma perguruan tinggi pada universitas bina insan lubuklinggau

\section{SARAN}

Saran yang dapat penulis sampaikan setelah melakukan penelitian dengan judul aplikasi pengelolahan data tri dharma perguruan tinggi pada universitas bina insan lubuklinggau berbasis web ialah pada aplikasi ini masih banyak kekurangan baik dari sisi tampilan maupun proses yang ada sehingga dapat dikembangkan pada penelitian selanjutnya.

\section{DAFTAR PUSTAKA}

[1] B. Lian, "TANGGUNG JAWAB TRIDHARMA PERGURUAN TINGGI MENJAWAB KEBUTUHAN MASYARAKAT," in Prosiding seminar nasional pendidikan program pascasarjana universitas pgri palembang 03 mei 2019, 2019, pp. 100-106.

[2] B. Intan and F. Rizki, "Dashboard Monitoring Application Community Research Reporting Lecturers And Students Of The University Bina Insan Lubuklinggau," J. Ilm.
BETRIK Besemah Teknol. Inf. dan Komput., vol. 11, no. 3, pp. 1-12, 2020.

[3] M. N. Rodhi, R. Hammad, K. A. Latif, and H. Pebrianti, "E Monitoring Tri Dharma Dosen Program Studi S1 Manajemen Universitas Bumigora Menggunakan Trello," J. Econ. Manag. Account., vol. 4, no. 1, pp. 73-84, 2021.

[4] A. H. Taryoto, "Analisis Karya Ilmiah Sebagai Komponen Tri Darma Perguruan Tinggi," J. Penyul. Perikan. dan Kelaut., vol. 9, no. 1, pp. 1-11, 2015, doi: 10.33378/jppik.v9i1.54.

[5] H. Setiaji and R. Kurniawan, "Sistem Informasi Penelitian dan Pengabdian Dosen Guna Otomatisasi Penentuan Angka Kredit Dosen dan Mendukung Aktivitas Tridharma Perguruan Tinggi," Semin. Nas. Apl. Teknol. Inf. 2011 (SNATI 2011). Bhs., vol. 2011, no. Snati, p. E-92-E-98, 2011, doi: ISSN: 1907-5022.

[6] D. Puspita and M. Anggita, "Penerapan Unified Modeling Language (Uml) Dalam Membangun Sistem Pengenalan Usaha Kecil Menengah (Ukm) Kota Pagaralam," JUSIM (Jurnal Sist. Inf. Musirawas), vol. 5, no. 2, pp. 103-110, 2020, doi: 10.32767/jusim.v5i02.805.

[7] D. Puspita, "Website Kebudayaan Sastra Besemah Kota Pagaralam," JUSIM (Jurnal Sist. Inf. Musirawas), vol. 4, no. 2, pp. 67-73, 2019, doi: 10.32767/jusim.v4i02.572.

[8] I. P. P. Satria Wibawa, A. A. A. P. Ardyanti, and I. G. J. Eka Putra, "Sistem Pemesanan Canang Dengan Menggunakan Framework Codeigniter," JUSIM (Jurnal Sist. Inf. Musirawas), vol. 4, no. 1, pp. 110, 2019, doi: 10.32767/jusim.v4i1.402. 
[9] D. Apriadi and R. Kuswandhie, "Sistem Pendukukung Keputusan Penentuan Jurusan Pada Sma Bina Satria," JUSIM (Jurnal Sist. Inf. Musirawas), vol. 5, no. 2, pp. 87-95, 2020, doi: 10.32767/jusim.v5i02.970.

[10] D. S. Purnia, A. Rifai, and S. Rahmatullah, "Penerapan Metode Waterfall dalam Perancangan Sistem Informasi Aplikasi Bantuan Sosial Berbasis Android," Semin. Nas. Sains dan Teknol. 2019, pp. 1-7, 2019.

[11] A. Zulius and N. K. Daulay, "SISTEM INFORMASI

GEOGRAFIS LOKASI WISATA

KULINER PADA KOTA

LUBUKLINGGAU BERBASIS ANDROID," JUSIM (Jurnal Sist. Inf. Musirwas), vol. 4, no. 2, pp. 109115, 2019. 